\title{
EDUCATION TECHNICAL COURSE FOR COLLEGE TEACHING FACULTY AT MU- RESEARCH PROBE
}

\section{Pavel PECINA}

\begin{abstract}
Article is devoted to the koncept of professional didactics (technical) courses for the Mathers teaching technical subjects at secondary techical school, specializing in engineering, trade and services and at the Pedagogical faculty of Masaryk Univerzity in Brno. The second part focuses on research probe, in which we focus on what students expect from the subject, how satisfied they are with teaching and learning how to evaluate the prepared material.
\end{abstract}

Key words: Departmental didactics, didactics of vocational subject, research probe.

\section{POJETÍ DIDAKTIKY TECHNICKÝCH PŘEDMĚTŮ PRO STŘEDNÍ ODBORNÉ ŠKOLY NA PEDAGOGICKÉ FAKULTĚ MU - VÝZKUMNÁ SONDA}

Resumé: Článek je věnován koncepci didaktiky odborných (technických) předmětů v magisterském studiu učitelství odborných predmětů na SOŠ, specializace strojírenství, obchod a služby a služby na Pedagogické fakultě MU v Brně. Druhá část př́spěvku je zaměřena na výzkumnou sondu, ve které jsme se zaméřili na to, co studenti od předmètu očekávají, jak jsou spokojeni s výukou a jak hodnotí pripravené studijní materiály.

Kličcová slova: Oborová didaktika, didaktika odborných předmètůư výzkumná sonda .

\section{1 Úvod}

Od školního roku 2008/2009 připravujeme na Pedagogické fakultě MU učitele odborných předmětů $\quad v$ magisterských studijních programech (specializace: obchod a služby, služby - speciální pedagogika). Od školního roku 2009/2010 u nás byl akreditován i magisterský studijní program specializace strojírenství. Magisterské studium máme v kombinované formě studia. Předložená studie je zaměřena na pojetí předmětu didaktika odborných (technických) předmětů pro tyto studia a také na výzkumnou sondu, kterou jsme provedli v rámci evaluace tohoto předmětu.

\section{Pojetí předmětu}

V magisterském studiu je předmět didaktika odborných předmětů zařazen do dvou semestrů (1. a 2. semestr). Časová dotace v kombinovaném studiu je celkem 20 hodin konzultací (10 hodin na semestr). Na konzultace potom navazují pro všechny obory semináře $\mathrm{z}$ didaktiky odborných předmětů. Vyučující předmětu didaktika odborných (technických) předmětů je autor tohoto článku. $\mathbf{V}$ magisterském studiu je tento předmět jedním ze stěžejních, protože přispívá $k$ př́ípravě budoucích učitelů odborných předmětů na SOŠ.

S problematikou didaktiky odborných (technických) předmětů je spojena otázka, jak koncipovat tento předmět tak, aby splnil své poslání. Svým pojetím a charakterem spadá do oborových didaktik (Čadílek, 2005). Didaktika odborných předmětů svým pojetím a obsahem nemůže postoupit na úroveň předmětových didaktik, protože složení adresátů je rozmanité a zasahuje více odborných predmětů. $Z$ hlediska vzdělávací praxe by to však bylo žádoucí. Do určité míry řešíme otázky předmětových didaktik $\mathrm{v}$ rámci seminářu $\mathrm{z}$ didaktiky odborných předmětů.

Didaktika odborných předmětů navazuje na obecně pedagogické, didaktické a psychologické disciplíny a čerpá z nich. Specifikum předmětu spočívá především v integraci vybraných obecně pedagogických a didaktických poznatků a jejich aplikaci na výuku technických odborných předmětů na SOŠ.

Předmět didaktika odborných (technických) předmětů je jedním z posledních stupňů prípravy studentů pro praktickou činnost výkonu učitelské profese (Semrád, Škrabal, 2007). Obecný nejvyšší cíl předmětu jsme stanovili jako osvojení vybraných vědomostí a dovedností z oblasti výukových cílů, organizačních forem, obsahu, vyučovacích principů, prostředků vyučování a metod vodborných technických předmětech ve vazbě na vědní disciplíny př́slušných oborů. $V$ návaznosti na stanovené obecné cíle předmětu jsme za pilíře didaktiky 
odborných předmětů stanovili následující stěžejní tematické okruhy, kterým se ve výuce a na konzultacích věnujeme:

- Vymezení problému, didaktika odborných předmětů v systému pedagogických věd.

- Vědecký a didaktický systém ve výuce odborných předmětů.

- Výukové cíle ve výuce odborných předmětů.

- Obsah výuky odborných předmětů.

- Uplatňování didaktických zásad v odborných př̀edmětech.

- Výukové metody ve výuce odborných předmětů:

- Charakteristika, rozdělení metod, kritéria volby metod.

- Metody slovní, názorně demonstrační a praktické.

- Aktivizující výukové metody, učební úlohy ve výuce odborných předmětů.

- Další varianty metod.

- Možnosti využití projektové výuky ve výuce odborných předmětů, skupinová a kooperativní výuka, Brainstorming.

- Metody opakování osvojeného učiva.

- Metody diagnostické a klasifikační ve výuce odborných předmětů.

- Organizační formy výuky v odborných předmětech.

- Učební pomůcky a didaktická technika ve výuce odborných předmětů, interaktivní tabule, prezentační techniky, možnosti využití prezentací, animací, simulací a dalších prostředků v odborných předmětech.Výukové opory.

- Plánování práce ve střední odborné škole, rámcové vzdělávací programy pro SOŠ.

- Osobnost učitele odborných předmětů.

U všech řešených témat klademe důraz na aplikační charakter a uvádíme specifika výuky př́slušných odborných oborů (předmětů). Aplikace je také demonstrována na př́kladech technických předmětů, zejména prŕiklady jednotlivých cílů obecnějších i konkrétních, př́klady uplatnění didaktických zásad, př́klady využití výukových metod, př́klady možného využití interaktivní tabule, výukových opor, prezentací, př́iklady konkrétních příprav apod. Ke zkoušce je nutné zvládnout teorii v rozsahu výše uvedených témat. Zkouška se skládá z písemné a ústní části. V písemné části studenti zpracují vylosovaná témata. U ústní zkoušky dostanou doplňující otázku podle uvážení vyučujícího. Přri zkoušce je sledována schopnost aplikovat didaktické poznatky na výuku př́slušného odborného předmětu a proto je velká část otázek aplikačních. Ke zkoušce mají studenti za úkol vypracovat dvě písemné př́pravy na výuku svého odborného předmětu, včetně možností využití moderních technologií (výuková prezentace pro studenty, možnosti využití multimediálních výukových opor, animací, simulací apod.). Základním a výchozím studijním materiálem k problematice je výuková prezentace, se kterou pracujeme ve výuce a na konzultacích. Prezentace je studentům volně dostupná $\quad \mathrm{v}$ informačním systému (www.is.muni.cz). V této době také dokončujeme inovaci učebního textu $\mathrm{k}$ dané problematice.

\section{Výzkumná sonda}

V souvislosti s evaluací koncepce nového předmětu „didaktika odborných předmětů“ v magisterském studiu jsme provedli analýzu anonymních odpovědí studentů $\mathrm{z}$ ankety $\mathrm{k}$ těmto předmětům za období podzim 2008, jaro 2009 a podzim 2009. Zaměřili jsme se na následující základní otázky:

- Co studenti očekávají od didaktiky technických předmětů (př́nos předmětu).

- Jak jsou spokojeni s výukou (zajímavost předmětu, přístup učitele, odbornost učitele) .

- Jak posuzují náročnost předmětu.

- Jak posuzují námi připravené studijní materiály.

Jako výzkumnou metodu jsme použili analýzu údajů $\quad \mathrm{z}$ anonymní předmětové ankety v informačním systému Masarykovy univerzity za období podzim 2008, jaro 2009 a podzim 2009. Při koncipování výzkumných otázek jsme vyšli z výše zmíněné anonymní ankety v informačním systému Masarykovy univerzity. Konkrétní otázky studenti posuzovali na následující škále:

\section{Zajímavost předmětu:}

není vůbec zajímavý.....(.).... je velmi zajímavý Přínosnost předmětu

není vůbec přínosný .....(.)..... je velmi přínosný

Obtížnost obsahu

velmi snadný .....(.)..... velmi obtížný

Náročnost na př́ípravu

velmi snadný $\quad$.....(.)..... velmi obtížný

Dostupnost studijních zdrojů

velmi špatné dostupné.....(.).....velmi dobřre dostupné

Jak učitel učí

velmi špatný .....(.)....vynikající 
není odborníkem .....(.).... je odborníkem

\section{Analýza získaných údajů}

Níže uvádíme škály z Informačního systému. $\mathrm{U}$ odpovědí písmeno $\mathrm{X}$ označuje průměr odpovědí a hvězdičky značí rozptyl odpovědí. První škála se vztahuje ke specializaci obchod a služby po období podzim 2008. Odpovědělo celkem 47 studentů z celkového počtu 93 studentů. Odpovědělo tedy $51 \%$ studentů.

\section{Zajímavost předmětu:}

není vůbec zajímavý .....(.)..* $\mathbf{X}^{*}$ je velmi zajímavý

Př́nosnost předmětu:

není vůbec př́nosné .....(.).** $\mathbf{X}^{*}$ je velmi přínosné

\section{Obtížnost obsahu:}

velmi snadný ...**(X)**... velmi obtížný

Náročnost na př́pravu:

velmi snadný ....***)X**.. velmi obtížný

Dostupnost studijních zdrojů:

velmi špatně dostupné .....(.).** $\mathbf{X}^{*}$ velmi dobře dostupné

Jak učitel učí:

velmi špatný .....(.).** $\mathbf{X}^{*}$ vynikající

Učitel jako odborník:

není odborníkem .....(.)..* $\mathbf{X}^{*}$ je odborníkem

Z výše uvedených odpovědí vyplývá, že se průměrné odpovědi i rozptyl nachází v převážně většině v pravé části škály. To je pro nás pozitivní zjištění. Výjimkou jsou odpovědi, vztahující se $\mathrm{k}$ náročnosti předmětu. $\mathrm{V}$ tomto príípadě se průměr odpovědi nachází uprostřed a rozptyl se nachází např́č celou škálou.

Následující škála se vztahuje k období jaro 2009. Odpovídalo celkem 57 studentů z celkového počtu 93 studentů ze specializace obchod a služby. Odpovědělo tedy $61 \%$ studentů.

Zajímavost předmětu:

není vůbec zajímavý .....(.).**X* je velmi zajímavý

Př́nosnost předmětu:

není vůbec př́nosné .....(.)** $\mathbf{X}^{* *}$ je velmi př́nosné

Obtížnost obsahu:

velmi snadný ...**(X)**... velmi obtížný

Náročnost na př́ípravu:

velmi snadný ....***) $\mathbf{X}^{* *}$.. velmi obtížný

Dostupnost studijních zdrojů:

velmi špatně dostupné ......(.)** $\mathbf{X}^{* *}$ velmi dobře dostupné
Jak učitel učí:

velmi špatný .....(.)** $\mathbf{X}^{* *}$ vynikající

Učitel jako odborník:

není odborníkem .....(.).** $\mathbf{X}^{*}$ je odborníkem

I v těchto př́padech se odpovědi studentů nachází v pravé částí škály. Opět tvoří výjimku obtížnost obsahu, která je v průměru. Rozptyl se také nachází např́ič celé škály.

$\mathrm{V}$ následující anketě anketě odpovídalo celkem 20 osob z celkového počtu 47 osob z magisterského studia, specializace strojírenství. Anketa se vztahuje na období podzim 2009. Odpovědělo tedy $43 \%$ studentů.

\section{Zajímavost předmětu:}

není vůbec zajímavý .....(*)*X**. je velmi zajímavý

Př́ńnosnost předmětu:

není vůbec př́nosné .....(.)**X** je velmi přínosné

\section{Obtížnost obsahu:}

velmi snadný ...**(X)**... velmi obtížný

Náročnost na př́ípravu:

velmi snadný ...**(X)**... velmi obtížný

Dostupnost studijních zdrojů:

velmi špatně dostupné .....(.)** $\mathrm{X}^{* *}$ velmi dobře dostupné

Jak učitel učí:

velmi špatný .....(.).**X* vynikající

Učitel jako odborník:

není odborníkem .....(.).**X* je odborníkem

Z výše uvedených odpovědí vyplývá, že se průměrné odpovědi i rozptyl nachází v převážně většině také $\mathrm{v}$ pravé části škály. To je pro nás pozitivní zjištění. Výjimkou jsou odpovědi, vztahující se $\mathrm{k}$ náročnosti předmětu. V tomto prŕpadě jsou průměrné odpovědi u obou položek v průměru a rozptyl se nachází naprríč celou škálou. U jednotlivých škál se také v několika př́ipadech objevily většinou anonymní komentáře $\mathrm{k}$ různým aspektům předmětu. Celkově jsme zaznamenali 8 následujících komentářu:

Přednášky velmi zajímavé.

Výborný výklad, prezentace a dostupnost studijních materiálů.

Přednášky probíhaly ve velmi dobré atmosférée, vyučující byl spíše kolegou a diskuse $\mathrm{k}$ tématům byly pro obě strany prŕnosem.Perfektní dostupnost materiálu, vstřícnost ze strany pedagoga. 
Hana Sladká

Při zkoušení jsem do testu napsala vše do podrobnosti, bohužel dr, Pecina mě vyloženě dusil, a bylo poznat, že mě nechce dát jedničku, myslím, že to není jen můj názor.Přes jeho př́ijemné

vystupování se mě nelíbí jeho přístup u zkoušek.

Bez připomínek.

Jsem přesvědčen, že pan doktor je na svém místě.

Děkuji za velmi krásně zpracované materiály ke studiu a Váš osobní př́stup ke studentům.

Př́ijemný projev při přednáškách.

Výše uvedené komentáře se vztahují ke komunikační stránce výuky a khodnocení studijních materiálů. Tyto aspekty byly posuzovány pozitivně. Objevil se jeden negativní komentář vztahující se k přístupu vyučujícího ke zkoušení. Odpovědí je bohužel málo a no, aby bylo možné získané údaje zobecnit.

\section{Shrnutí a závěry}

Výzkumné sondy se zúčastnilo celkem 124 studentů $\mathrm{z}$ celkového počtu 233 studentů, kteří studovali tento př̀edmět celkově 3 semestry studia. Z tohoto počtu bylo 104 studentů, kteří ve školním roce 2009/2010 studují 2. ročník magisterského studia a hodnotili předmět didaktika odborných předmětů za oba semestry studia (1. a 2 . semestr). Dále se ankety zúčastnilo 20 studentů, kteří ve školním roce 2009/2010 studují 1. ročník magisterského studia. Tito studenti hodnotili jeden semestr studia. Ankety se celkově zúčastnilo 53\% studentů. $\mathrm{Z}$ uvedených škál je patrné, že předmět je ve sledovaných ukazatelích hodnocen spíše pozitivně. V průměru se nachází položky vztahující se k náročnosti předmětu. $\mathrm{Na}$ základně odpovědí se domníváme, že pojetí tohoto předmětu se ubírá pozitivním směrem. Stejnou výzkumnou sondu chceme provést i za období jaro 2010 pro specializací strojírenství a výsledky porovnat s výše zjištěnými údaji. $\mathrm{V}$ další práci máme $\mathrm{v}$ plánu se zaměřit na úroveň znalostí studentů, které získaly $\mathrm{v}$ tomto předmětu. $\mathrm{V}$ tom př́padě bude třeba vytvořit odpovídající výzkumný nástroj (vstupní a výstupní didaktický test), na základě kterého budeme údaje získávat. Posuzovat budeme přidanou hodnotu vzdělání.

\section{Literatura}

[1] BAJTOŠ, J. Didaktika technických predmetov. Žilina: Žilinská univerzita v Žilině,1999. ISBN 80-7100-646-7

[2] ČADILEK, M. LOVEČEK, A. Didaktika odborných předmětů, Brno: Pdf MU, 2005.

[3] DRAHOVZAL, J. KILIAN, O., KOHOUTEK, R. Didaktika odborných předmětů. Brno, 1997. ISBN 80-85931-35-4.

[4] FRIEDMANN, Z. Didaktika technické výchovy. Brno: MU, 1993. ISBN 80-210-0764-8.

[5] KOLEKTIV AUTORŮ. Evropské souvislosti změn odborného vzdělávání. Praha: NUOV, 2008.

[6] KOŽUCHOVÁ, M. POMŠÁR, Z. KOŽUCH, I. Fenomén techniky vo výchove a vzdělávání $v$ základném škole. Bratislava: UK, 1997. ISBN 80-223-1135-9.

[7] KROPÁČ́, J a kol. Didaktika technických predmětù, vybrané kapitoly. Olomouc: UP, 2004. ISBN 80-244-0848-1.

[8] MOŠNA, F., RÁDL, Z. Problémové vyučování a učení vodborném školství. Praha: Pedagogická fakulta UK, 1996.

ISBN 80-902166-0-9.

[9] PECINA, P. Didaktika odborných předmětů v př́pravě učitelů praktického vyučování a učitelů odborných předmětů na pedagogické fakultě MU. In. Co je nového v didaktikách odborných predmétů a odborného výcviku. Kostelec nad Černými lesy: NUOV, 2009. ISBN 978-80-87063-25-5

[10] SEMRÁD, J., ŠKRABAL, M. Úvod do studia učitelství odborných predmétu. Praha: ČVUT, 2007. ISBN 978- 80-01-03744-7.

[11] TUREK, I. Didaktika technických predmetov. Bratislava: SPN, 1990.

ISBN 80-08-00587-4.

[12] www.is.muni.cz

Mgr. Pavel Pecina, Ph.D.

Katedra didaktických technologií

Pedagogická fakulta MU

Poříčí 31, 60200 Brno, ČR

Tel: +420 549495488

E-mail: ppecina@ped.muni.cz 